rozpoczęcie prac legislacyjnych w tym zakresie. W styczniu 2016 r. Ministerstwo Finansów przekazało do konsultacji projekt ustawy o zasadach rozliczeń w podatku od towarów i usług oraz dokonywania zwrotu środków europejskich przez jednostki samorządu terytorialnego oraz o zmianie ustawy o finansach publicznych (Projekt, 2016).

\title{
Literatura
}

Bartosiewicz, A. (2015a). VAT Komentarz. Warszawa: Wolters Kluwer.

Bartosiewicz, A. (2015b). Wykonując zadania własne gmina może być podatnikiem VAT. Finanse Komunalne, 2.

Błędowski, A. (2015). Gmina i jej jednostki budżetowe są jednym podatnikiem. Rzeczpospolita, 12 października 2015.

Bucior, G. (2014). Podmiotowość samorządowej jednostki budżetowej w systemie podatku VAT. W: H. Lelusz (red.), Metodyczne aspekty badań w rachunkowości. Olsztyn: Wydawnictwo Uniwersytetu WarmińskoMazurskiego.

Czarny, K. (2011). VAT w sektorze publicznym. Wrocław: Presscom Sp.z o.o.

de la Feria, R. (2016). EU VAT Principles as Interpretative Aids to EU VAT Rules: The Inherent Paradox. W: M. Lang (red.), Recent VAT Case Law of the CJEU. Linde.

Feret, E. (2013). Formy organizacyjno-prawne finansowania samorządowych zadań publicznych. Rzeszów: Wydawnictwo WBX Studio Graficzne.

Gibasiewicz, D. (2012). Zasada neutralności podatku od wartości dodanej w orzecznictwie Trybunatu Sprawiedliwości Unii Europejskiej. Warszawa: Wolters Kluwer Polska.

Głuchowski, J. (2006). Polskie prawo podatkowe. Warszawa: LexisNexis.

Janczukowicz, K., Kieszkowski, W. (2015). Podatki pośrednie w praktyce. Gdańsk: ODDK.

Kosek-Wojnar, M. (2012). Zasady podatkowe w teorii i praktyce. Warszawa: PWE.

Maj, M. (2014). Fiskus ogranicza prawo do odliczenia podatku. Rzeczpospolita, 9 grudnia 2014.

Maruchin, W. (2009). VAT w prawie polskim i prawie wspólnotowym: dyrektywa 2006/112/WE. Warszawa: Wiedza i Praktyka.

Maśloch, G., Sierak, J. (red.). (2013). Gospodarka i finanse samorzadu terytorialnego. Warszawa: Oficyna Wydawnicza Szkoła Główna Handlowa.

Militz, M. (2013). Zasady prawa unijnego w VAT. Warszawa: Wolters Kluwer Polska.

Orzeczenie Trybunału Sprawiedliwości Unii Europejskiej z 29 września 2015, C-276/14.

Projekt ustawy o zasadach rozliczeń w podatku od towarów i usług oraz dokonywania zwrotu środków europejskich przez jednostki samorządu terytorialnego oraz o zmianie ustawy o finansach publicznych z dnia 14 stycznia 2016, legislacja.rcl.gov.pl/projekt/12281103 (20.02.2016).

Rogala, E. (2014). VAT w gminach 2014. Warszawa: Difin.

Rogala, E. (2016). Jak gmina odlicza VAT w 2016 r. Rzeczpospolita, 1 marca 2016.

Sachs, K. (red.). (2003). VI Dyrektywa VAT: komentarz do Dyrektyw Rady Unii Europejskiej dotyczacych wspólnego systemu podatku od wartości dodanej. Warszawa: C.H. Beck, Ernst\&Young.

Sokołowska, E. (red.). (2015). VAT w jednostkach sektora finansów publicznych. Warszawa: Wydawnictwo C.H. Beck.

Wolska, H. (2014). Prowadzenie działalności gospodarczej przez gminę z wieloma ograniczeniami. Finanse Komunalne, 3.

Zaborniak, P. (2004). Granice działalności gospodarczej podmiotów komunalnych. Przemyśl: Wyższa Szkoła Administracji i Zarządzania.

Zasady odliczania VAT przy prowadzeniu działalności o charakterze mieszanym - ze zmianami wprowadzonymi od 1 stycznia 2016 r. (2016). Pobrane z: www.finanse.mf.gov.pl (20.02.2016).

Zubrzycki, J. (2016). Leksykon VAT 2016. T. 1. Wrocław: Oficyna Wydawnicza Unimex.

\section{VAT NEUTRALITY IN COMMUNITY}

Abstract: Purpose - the aim of the article is to present the problems of the functioning of the municipal organizational units in the Polish VAT system in the context of the fundamental principles of this system - the principle of neutrality and the associated rules called as right to deduct. Design/Methodology/Approach - critical analysis of the literature review, the study of source documents. Findings - implementation of the principle of neutrality of VAT is to create such legislative solutions to the taxpayer could deduct input tax is part of 
expenditures made in connection with the activities taxed. In the case of municipalities it is quite important that the exclusion of the principle of neutrality causes unreasonable, excessive taxation community uses the services provided by municipal entities if these services are subject to VAT. Meanwhile, the tax office refuses to municipalities to deduct VAT included in the investments used for taxable activities. Only winning the dispute of the City of Wrocław caused a change in the approach of the tax authorities to this issue. But still to solve many issues related to the proper application of the principle of neutrality of VAT by the municipality.

Keywords: the principle of neutrality of VAT, right to deduct VAT, municipality for VAT, the VAT in the village

\section{Cytowanie}

Bucior, G. (2016). Neutralność podatku od towarów i usług w gminie. Finanse, Rynki Finansowe, Ubezpieczenia, 2/2 (80), 227-234. DOI: 10.18276/frfu.2016.2.80/2-24; www.wneiz.pl/frfu. 
Finanse, Rynki Finansowe, Ubezpieczenia nr 2/2016 (80), cz. 2

\title{
Standaryzacja rachunkowości budżetowej
}

\author{
Monika Wakula*
}

\begin{abstract}
Streszczenie: Cel - próba wskazania uwarunkowań standaryzacji rachunkowości sektora publicznego w Polsce i UE oraz korzyści płynących z wdrożenia regulacji międzynarodowych Metodologia badania - analiza literatury oraz aktów prawnych dotyczących Międzynarodowych Standardów Sprawozdawczości Finansowej, Międzynarodowych Standardów Rachunkowości Sektora Publicznego. Wynik - Międzynarodowe Standardy Rachunkowości Sektora Publicznego w znacznym stopniu przyczyniłyby się do generowania przez system rachunkowości memoriałowej informacji porównywalnych zarówno na szczeblu międzynarodowym jak i krajowym. Oryginalność/Wartość - analiza wykazała, że w Polsce istnieją przesłanki wprowadzenia standaryzacji rachunkowości jednak nie ma akceptacji przez organy rządzące na wprowadzenie Międzynarodowych Standardów Rachunkowości Sektora Publicznego.
\end{abstract}

Slowa kluczowe: zasada memoriałowa, zasada kasowa, Międzynarodowe Standardy Rachunkowości Sektora Publicznego

\section{Wprowadzenie}

W literaturze przedmiotu sektor publiczny jest definiowany jako sektor, z którego wyłączono przedsiębiorstwa zarobkowe. Zalicza się do niego głównie organy władzy publicznej i podległe im jednostki organizacyjne, a także jednostki samorządu terytorialnego i ich organy oraz podległe im jednostki organizacyjne. Wspólną cechą podmiotów sektora publicznego jest wykonywanie zadań publicznych, w związku z czym są one finansowane ze środków publicznych. Są one objęte jednakowym reżimem prawnym, odnoszącym się do określonych w prawie zasad gospodarki finansowej.

W sektorze publicznym ważnym elementem służącym do kontroli i ochrony mienia publicznego oraz rozliczenia kadr zarządzających $\mathrm{z}$ odpowiedzialności wobec polityków i społeczeństwa jest rachunkowość. Odpowiedzialność społeczna powoduje konieczność zapewnienia zainteresowanym stronom właściwych, wiarygodnych i porównywalnych informacji pochodzących z rachunkowości (Kostrzewa, 2007, s. 167).

W niektórych obszarach stopień szczegółowości zasad rachunkowości, odnoszących się do jednostek sektora publicznego, jest niewystarczający, w skutek czego przy sporządzaniu sprawozdań finansowych pojawiają się liczne wątpliwości. Zgodnie z ustawą o rachunkowości (Ustawa o rachunkowości, 2013), jednostki sektora prywatnego, w sytuacjach przez nią nieuregulowanych mogą skorzystać z Krajowych Standardów Rachunkowości (KSR). Jeżeli zaś nie ma odpowiedniego KSR to wtedy zastosowanie mają Międzynarodowe Standardy Rachunkowości (MSR). Dla jednostek sektora publicznego zostały również skonstruowane odpowiednie standardy mające na celu ujednolicenie zasad rachunkowości budżetowej. Są to Międzynarodowe Standardy Rachunkowości Sektora Publicznego

\footnotetext{
* dr Monika Wakuła, Uniwersytet Przyrodniczo-Humanistyczny w Siedlcach. e-mail: monikawakula@wp.pl
} 
(MSRSP) (Kaczurak-Kozak, 2013,s. 102). W chwili obecnej mają one charakter rekomendacji i występują w postaci oferty złożonej przez międzynarodową organizację księgowych organom standaryzującym rachunkowość w poszczególnych krajach.

Celem artykułu jest próba wskazania uwarunkowań standaryzacji rachunkowości sektora publicznego w Polsce i UE oraz korzyści płynących ze stosowania regulacji międzynarodowych. Przyjęte metody badawcze opierają się głównie na analizie literatury oraz aktów prawnych i wnioskowaniu.

\section{Rachunkowość jednostek sektora publicznego i możliwości jej międzynarodowego ujednolicenia}

Potrzeby informacyjne rządzących i wykorzystywanie informacji generowanych przez rachunkowość determinowane są sposobem zarządzania sektorem publicznym. W modelu tradycyjnym, który polega głównie na administrowaniu dominuje rachunkowość według zasady kasowej. Koncentruje się ona w szczególności na wykonaniu budżetu opartego na klasycznych zasadach budżetowych.

Na skutek postępującej decentralizacji władzy publicznej i umocnienia samorządności lokalnej wykształcił się nowy sposób zarządzania sektorem publicznym definiowany jako New Public Management (NPM). Zapoczątkował on m.in.: oszczędne dysponowanie zasobami, zarządzanie $\mathrm{z}$ większą odpowiedzialnością, polegające na położeniu większego nacisku na realizację zadania $w$ taki sposób aby była możliwość pomiaru rezultatów działań i ich porównanie $\mathrm{z}$ określonymi standardami. Zmiana podejścia do zarządzania sektorem publicznym zapoczątkowała proces wdrażania modeli posiadających większe możliwości informacyjne. Jednym z nich jest model rachunkowości oparty na zasadzie memoriałowej (Zysnarska, 2010).

W większości krajów Unii Europejskiej, również w Polsce, w rachunkowości budżetowej, a szczególnie w rachunkowości jednostek samorządu terytorialnego wykorzystuje się jeszcze zasadę kasową. W rachunkowości prowadzonej według tej zasady podstawowymi kategoriami są przepływy środków pieniężnych. W tym ujęciu, transakcje i zdarzenia ujmowane są w księgach niezależnie od momentu realizacji umowy, tylko wtedy, gdy następuje faktyczny wpływ środków pieniężnych na rachunek bankowy lub ich wypłata. Konsekwencją tego może być zaksięgowanie dochodów i wydatków budżetowych w innym roku obrachunkowym niż ten, którego one dotyczą. Przy zastosowaniu tej metody podstawowym problemem jest posiadanie odpowiednich środków pieniężnych w określonym czasie, ich wydatkowanie zgodzie z ustalonym limitem a nie zadanie, na które te środki finansowe zostały przeznaczone. Ujęcie to nie sprzyja analizie skuteczności realizacji zadań wykonywanych przez jednostki sektora publicznego (Filipiak 2009, s. 149).

Kolejną niedoskonałością stosowania zasady kasowej stosowanej w rachunkowości budżetowej, a szczególnie w rachunkowości jednostek samorządu terytorialnego jest brak obowiązku tworzenia rezerw na należności i zobowiązania. Może to wpływać na wiarygodność informacji o nadwyżce bądź deficycie budżetowym na skutek przyspieszenia lub opóźnienia regulowania płatności (Winiarska, Kaczurak-Kozak, 2010, s. 34).

Na podstawie przytoczonych wad rachunkowości budżetowej z zastosowaniem zasady kasowej można stwierdzić, że informacje generowane przez nią nie mogą stanowić podstawy podejmowania decyzji ekonomicznych Mogą być tylko one podstawą do oceny ich zgodności z założonymi limitami. 
W związku z tym, że metoda kasowa nie dostarcza rzetelnych i wiarygodnych informacji, które pozwoliłyby na rozliczenie władz z dysponowania środkami publicznymi, należy dążyć do stworzenia docelowego systemu ewidencji budżetowej, który umożliwiłby równoległe śledzenie ruchu pieniądza i realizacji zadania, na które dane środki były przekazane. Pozwoliłoby to zwiększyć skuteczność realizacji zadań publicznych. Można tego dokonać poprzez przejście z ewidencji opartej na zasadzie kasowej na rzecz ewidencji według zasady memoriałowej. Miałaby ona zastosowanie w przypadku ewidencji stanu majątku, kosztów i przychodów, funduszy i wyniku finansowego. Za wprowadzeniem tej zasady opowiadają się również podmioty działające w kierunku standaryzacji rachunkowości budżetowej w krajach Unii Europejskiej.

W sprawozdaniu Komisji Europejskiej przeznaczonym dla Rady i Parlamentu Europejskiego w sprawie wprowadzenia Międzynarodowych Standardów Rachunkowości Sektora Publicznego (MSRSP) zaznaczono, że jednym powszechnie przyjętym systemem informacyjnym, zapewniającym kompletny i wiarygodny obraz sytuacji finansowej i gospodarczej oraz wyników działalności sektora instytucji samorządowych jest rachunkowość memoriałowa. Przedstawia ona w całości aktywa i zobowiązania, a także przychody i wydatki konkretnych jednostek w okresie objętym ewidencją oraz w momencie, w którym zostają one zamknięte. Autorzy przytaczanego sprawozdania wskazują, że wprowadzenie tej rachunkowości w sektorze publicznym jest konieczne aby uniknąć manipulowania wynikami, na co pozwala rachunkowość kasowa.

Rachunkowość budżetowa jest zróżnicowana zarówno w poszczególnych krajach jak i na poziomie międzynarodowym. W różnorodny sposób ujmowane są zasady wyceny składników majątkowych, informacje o transakcjach finansowych i operacjach gospodarczych w sprawozdaniach budżetowych i finansowych. Elementem łączącym rachunkowość sektora publicznego krajów europejskich jest stosowanie w różnym wymiarze zasad rachunkowości memoriałowej i kasowej, a także silna potrzeba wygenerowania porównywalnych informacji zawartych w sprawozdaniach finansowych (Adamek-Hyska, 2011).

Szczególny brak porównywalnych informacji dał się odczuć w chwili światowego kryzysu. Dostrzeżono wtedy głęboką kwalitatywną i kwantytatywną lukę informacji o długu publicznym. W celu jej likwidacji władze Unii Europejskiej zdecydowały się zmienić i ujednolicić system informacji w zakresie finansów publicznych. Zmiany miały objąć rachunkowość i sprawozdawczość sektora publicznego oraz bazować na jednolitych i obligatoryjnych europejskich standardach tj: European Public Sector Accounting Standards (EPSAS). Standardy zostałyby oparte na MSRSP (International Public Sector Accounting Standards - IPSAS) (Nowak, 2015, 149).

MSRSP po raz pierwszy ukazały się w 2000 roku. Na początku było ich 8 . W kolejnych latach lista ta się wydłużała. Obecnie wydanych jest 38 standardów bazujących na zasadzie memoriałowej oraz jeden dotyczący sprawozdań finansowych sporządzanych według zasady kasowej. Stosowanie tego standardu powinno doprowadzić do zapewnienia ponadnarodowej porównywalności sprawozdań finansowych sporządzanych na bazie kasowej (Zysnarska, 40).

MSRSP powstają na podstawie MSR i MSSF. Zastosowanie standardów rachunkowości dotyczących sektora publicznego stwarza ogromną szansę na zwiększenie porównywalności danych zarówno w wymiarze wewnętrznym, jak i zewnętrznym. W wymiarze wewnątrzkrajowym pojawia się możliwość porównywania gospodarki rządowej z gospodarką samorządową. W wymiarze zewnętrznym standaryzacja stwarzałby natomiast możliwość 
dokonania wiarygodnej oceny skuteczności działania rządów lub oceny sytuacji gospodarczej wybranych krajów (Adamek-Hyska, 2011).

Należy podkreślić, że standaryzacja rachunkowości sektora publicznego będzie procesem długotrwałym. MSRSP nie mają obecnie wiążącej mocy prawnej, nakazującej bezwarunkowe przyjęcie ich przez kraje europejskie. Jak zaznacza K. Winiarska w swoich publikacjach (Winiarska, Kaczurak-Kozak, 2010), Rada MSRSP zachęca do zastosowania tworzonych przez nią standardów lub przynajmniej do zharmonizowania z nimi wytycznych krajowych.

Rozwój standardów jest promowany i finansowany przez organizacje takie jak: Międzynarodowy Fundusz Walutowy, Bank Światowy oraz rządy krajów rozwiniętych. Z analizy zagadnień związanych $\mathrm{z}$ wprowadzeniem MSRSP na arenie międzynarodowej wynika, że obecnie 60 krajów stosuje lub przygotowuje się do stosowania ich jako podstawy sporządzania sprawozdań finansowych. Jednak w żadnym kraju Unii Europejskiej nie doszło do całkowitego zaadaptowania MSRSP. Można zauważyć częściowe ich zastosowanie $\mathrm{w}$ wybranych obszarach sektora publicznego lub dopiero rozpoczęcie procedury przechodzenia z rachunkowości kasowej na rachunkowość memoriałową. W Niemczech np. MSRSP są stosowane w Ministerstwie Finansów, policji, Ministerstwie Spraw Zagranicznych, Ministerstwie Sprawiedliwości, urzędach pracy i administracji lokalnej. Na Słowacji standardy zastosowano natomiast w Ministerstwie Finansów i Ministerstwie Obrony Narodowej (Garbiński, Kędzior, 2009, s. 150). MSRSP wdrożyły częściowo lub całościowo również organizacje takie jak: OECD, NATO, ONZ czy Komisja Europejska. Ostatnia $\mathrm{z}$ wymienionych organizacji wdrożyła standardy $\mathrm{w}$ pełnym wymiarze. Było to spowodowane celami, jakie powinien spełniać system rachunkowości Unii Europejskiej. Po pierwsze rachunkowość ta powinna dostarczać informacje, o stopniu realizacji budżetu Parlamentowi Europejskiemu, Radzie Unii Europejskiej oraz obywatelom państw członkowskich (Grybauskaite, Devlin, 2008, s. 28). Drugim celem jest zaprezentowanie za dany rok sprawozdania finansowego, obejmującego bilans, który jest opisem sytuacji finansowej Unii wraz ze stanem aktywów i zobowiązań na koniec roku obrachunkowego (Grybauskaite, Devlin, 2008, s. 28).

\section{Standaryzacja rachunkowości budżetowej w Polsce}

W Polsce również jest widoczne zainteresowanie standaryzacją rachunkowości w sektorze publicznym. Wynika to częściowo ze zmian szczególnych zasad rachunkowości wprowadzonych w 2006 roku. Na mocy tych przepisów jednostki budżetowe i zakłady budżetowe zaczęły sporządzać, oprócz bilansu, rachunek zysków i strat w wariancie porównawczym oraz zestawienie zmian w funduszu jednostki. Skutkiem tych zmian było zbliżenie rachunkowości budżetowej do rachunkowości stosowanej w sektorze prywatnym i do rachunkowości zasobów, opartej na zasadzie memoriałowej i na kanonicznym modelu sprawozdawczym (Adamek-Hyska, 2011).

Kolejna przyczyna zainteresowania standaryzacją rachunkowości budżetowej wynika z podpisania podczas polskiej prezydencji w Unii Europejskiej tzw: „Sześciopaku” czyli dyrektywy Rady 2011/85/UE z dnia 8 listopada 2011 r. w sprawie wymogów dla ram budżetowych państw członkowskich. Określała ona szczegółowe zasady w zakresie właściwości ram budżetowych państw członkowskich. Było to niezbędne w celu zapewnienia przestrzegania obowiązków państw członkowskich wynikających z Traktatu o funkcjono- 
waniu Unii Europejskiej w odniesieniu do unikania nadmiernego deficytu publicznego (Kaczurak-Kozak, 2013). Zasady zawarte w omawianej dyrektywnie odnoszą się do siedmiu obszarów. Jednym z nich jest rachunkowość, w stosunku do której zapisano: „funkcjonowanie kompletnej i wiarygodnej rachunkowości we wszystkich subsektorach sektora finansów publicznych jest warunkiem wstępnym do uzyskania wysokiej jakości danych statystycznych, porównywalnych w skali Unii Europejskiej” (Nowak, 2015, s. 149). Dlatego też na władzach sektora finansów publicznych ciąży obowiązek zapewnienia działania systemu rachunkowości publicznej obejmującego księgowość, kontrole wewnętrzną, sprawozdawczość finansową i audyt (Nowak, 2015). System ten powinien odróżniać się od systemów danych statystycznych, których przedmiotem są wyniki finansów publicznych i od działań prognostycznych oraz budżetowych, które dotyczą przyszłych stanów finansów publicznych. Regulacja ta ma wymuszać stosowanie przyjętych reguł we wszystkich subsektorach finansów publicznych, a dokonywany przez np. NIK lub RIO bądź przez prywatne firmy audytorskie niezależny audyt finansowy ma zachęcać i pobudzać do korzystania z najlepszych praktyk międzynarodowych.

System rachunkowości funkcjonujący obecnie w Polsce generuje informacje finansowe ściśle zorientowane na potrzeby organów administracji i władzy. Zgodzić należy się z W.A. Nowakiem (Nowak, 1988, s. 186), że informacje otrzymane z tak funkcjonującego systemu rachunkowości są w bardzo małym stopniu neutralne i obniża to ich wartość ekonomiczną. Rozwiązaniem tego problemu mogłoby być wprowadzenie standardów rachunkowości sektora publicznego opartych w pełni na zasadzie memoriałowej. Wśród korzyści z zastosowania MSRSP w Polsce wymieniane są (Zaczyński, 2012, s. 30): 1) poprawa jakości sprawozdawczości finansowej - większa przejrzystość prezentowanych informacji; 2) większa efektywność zarządzania finansami publicznymi - rzetelniejsza ocena sytuacji majątkowo-finansowej, zadłużenia, ułatwienie podejmowania decyzji inwestycyjnych; 3) ujednolicenie zasad rachunkowości wewnątrz UE - możliwość porównywania sprawozdań finansowych na płaszczyźnie międzynarodowej; 4) nowe rozwiązania dla samorządów - standardy odnoszą się do zagadnień sprawiających problemy w sprawozdawczości finansowej jednostek samorządu terytorialnego.

$\mathrm{W}$ celu ujednolicenia polskich rozwiązań w zakresie rachunkowości budżetowej z rachunkowością budżetową w innych krajach, w naszym ustawodawstwie, regulującym zasady prowadzenia gospodarki finansowej w jednostkach sektora publicznego, zapisano zobowiązanie, aby plany kont budżetu państwa, budżetu jednostek samorządu terytorialnego, jednostek budżetowych oraz zakładów budżetowych uwzględniały zasady zawarte w ustawie o rachunkowości i standardach międzynarodowych. Nie wskazano jednak, które standardy należałoby uwzględnić: czy MSR, MSSF czy MSRSP. Biorąc pod uwagę zapis ustawy o rachunkowości, że: w sprawach nieuregulowanych przepisami tego aktu prawnego każdy podmiot ma prawo zastosować MSR, można wnioskować, że dla podmiotów sektora publicznego mają zastosowanie również MSR. Potwierdza to brak thumaczenia MSRSP na język polski. Również dość krytycznie na temat MSRSP wypowiada się Ministerstwo Finansów. Przedstawiciele resortu jako główne wady MSRSP wymieniają (Odpowiedź podsekretarza stanu, 2012): 1) zbytnie zbliżenie MSRSP do MSSF przeznaczonych dla jednostek sektora prywatnego, co powoduje konieczność sporządzania sprawozdań i ujawnień zgodnie z potrzebami inwestorów, którzy nie są podstawowymi odbiorcami sprawozdań finansowych sektora publicznego; 2) złożoność zasad i skomplikowany poziom MSRSP może przekreślić możliwość ich zastosowania przez mniejsze podmioty działające w sektorze publicznym; 3) brak regulacji zasad dotyczących kluczowych obszarów funkcjonowa- 
nia sektora publicznego, np: transferów społecznych; 4) dopuszczenie różnych wariantów rozwiązań, co może prowadzić do odmiennego ujmowania $\mathrm{w}$ księgach rachunkowych podmiotów publicznych tożsamych zdarzeń i do spadku porównywalności ich sprawozdań finansowych.

Ministerstwo Finansów zwraca również uwagę na koszty wdrożenia MSRSP. Wprowadzenie standaryzacji wymagałoby dużych wydatków w związku z identyfikacją i wyceną składników aktywów, opracowaniem stosownej polityki rachunkowości, wdrożeniem odpowiednich narzędzi informatycznych, szkoleniem służb finansowo-księgowych.

Zgodzić się należy z D. Adamek-Hyska (2011, s. 83), że w Polsce standaryzację rachunkowości sektora publicznego utrudnia również brak zespołów badawczych, podkomisji Komitetu Krajowych Standardów Rachunkowości oraz zespołów konsultacyjnych, które zidentyfikowałyby problemy szczegółowych instytucji i organizacji sektora publicznego.

\section{Uwagi końcowe}

Władze sektora publicznego gospodarują publicznymi zasobami finansowymi. Ważne jest, aby te środki były wydatkowane w sposób celowy, oszczędny i efektywny. Zarządzanie nimi jest poddane ocenie społeczeństwa. Dokonuje się ona głównie na podstawie sprawozdań finansowych. Dlatego tak istotne jest, aby zawarte w nich informacje były wiarygodne i umożliwiały porównania zarówno wewnątrz danego kraju, jak i na arenie międzynarodowej. Z przeprowadzonych rozważań wynika, że sporządzane obecnie sprawozdania finansowe na podstawie rachunkowości prowadzonej według zasady kasowej, nie zapewniają takich informacji. W zawiązku z tym należałoby dążyć do zmiany rachunkowości kasowej na rachunkowość memoriałową. Rachunkowość memoriałowa stanowi też warunek wprowadzenia MSRSP. Standardy te zostały częściowo wdrożone w 60 krajach. W Polsce, pomimo wielu zalet standaryzacji, nie ma jej akceptacji ze strony osób sprawujących władzę. Jako jedną z głównych przyczyn wskazywane są wysokie koszty nierównoważące korzyści potencjalnych zmian.

\section{Literatura}

Adamek-Hyska, D. (2011). Kierunki harmonizacji rachunkowości jednostek sektora publicznego. W: A. Kostur (red.), Problemy harmonizacji rachunkowości (s. 66-84). Katowice: Wydawnictwo Uniwersytetu Ekonomicznego.

Filipiak, B., Gorzałczyńska-Koczkodaj, M. (red.). (2007). Finanse samorządowe. Narzędzia - decyzje-procesy. Warszawa: PWN.

Filipiak, B. (2009). Metodyka kompleksowej oceny gospodarki finansowej jednostki samorzadu terytorialnego. Warszawa: Difin.

Garbiński, K., Kędzior, M. (2009). Międzynarodowe Standardy Rachunkowości Sektora Publicznego. W: B. Micherda (red.), Ewolucja prawnych rozwiazań wspótczesnej rachunkowości. Warszawa: C.H. Beck.

Grybauskaite, D., Devlin, D. (2008). Nowy system rachunkowości UE. Luksemburg: Urząd Oficjalnych Publikacji Wspólnot Europejskich.

Kaczurak-Kozak, M. (2013). Charakter Międzynarodowych Standardów Rachunkowości Sektora Publicznego i ich przydatność - opinie. Zeszyty Naukowe Uniwersytetu Szczecińskiego, 765, Finanse, Rynki Finansowe, Ubezpieczenia, 61 t.2, 101-107.

Kostrzewa, T. (2007). Standardy sprawozdawczości finansowej sektora publicznego w Stanach Zjednoczonych. W: W.Gabrusewicz (red.), Rachunkowość w teorii i praktyce. Poznań: Akademia Ekonomiczna.

Nowak, W.A. (1998). Rachunkowość sektora publicznego. Koncepcje, metody uwarunkowania. Warszawa: PWN. 
Nowak, W.A. (2015). Ku standaryzacji rachunkowości sektora publicznego w Unii Europejskiej. Prace Naukowe Uniwersytetu Ekonomicznego we Wrocławiu, 388, Teoria rachunkowości, sprawozdawczość i analiza finansowa, 148-158.

Odpowiedź podsekretarza stanu w Ministerstwie Finansów na zapytanie nr 1304 w sprawie przeprowadzenia oceny przydatności międzynarodowych standardów rachunkowości sektora publicznego. Pobrano z: www.sejm.gov.pl (25.01.2016)

Sprawozdanie Komisji dla Rady i Parlamentu Europejskiego: W kierunku wdrożenia zharmonizowanych standardów rachunkowości sektora publicznego w państwach członkowskich. Przydatność MSRSP dla państw członkowskich. Pobrane z: http://eur-lex.europa.eu/legal-content/PL/TXT/?uri=CELEX\%3A52013DC0114 (20.01.2016)

Ustawa z dnia 29 września 1994 r. o rachunkowości. Dz.U. 2013, poz.330, z późn. zm.

Winiarska, K., Kaczurak-Kozak, M. (2010). Rachunkowość budżetowa. Warszawa: Wolters Kluwer.

Zaczyński, P. (2012). Międzynarodowe Standardy Rachunkowości Sektora Publicznego, Finanse Publiczne, 7.

Zysnarska, A. (2010), Rachunkowość budżetowa w świetle koncepcji prawdziwego i wiernego obrazu. Gdańsk: Wydawnictwo Uniwersytetu Gdańskiego.

\section{BUDGET ACCOUNTING STANDARDIZATION}

Abstract: Purpose - an attempt to determine the conditioning of accounting standardization of the public sector in Poland as well as benefits from implementing international regulations. Design/Methodology/ Approach - the analysis of literature and legal acts concerning International Financial Reporting Standard, International Public Sector Accounting Standards. Findings - International Public Sector Accounting Standards would significantly contribute to generating accrual information by the accounting system, which would be comparable at the domestic and international level. Originality/Value - the analysis showed that there are conditions for implementing accounting standards in Poland, however, the introduction of International Public Sector Accounting Standards is not accepted by governing authorities.

Keywords: accrual basis, cash basis, International Public Sector Accounting Standards (IPSAS)

\section{Cytowanie}

Wakuła, M. (2016). Standaryzacja rachunkowości budżetowej. Finanse, Rynki Finansowe, Ubezpieczenia, 2/2 (80), 235-241. DOI: 10.18276/frfu.2016.2.80/2-25; www.wneiz.pl/frfu. 